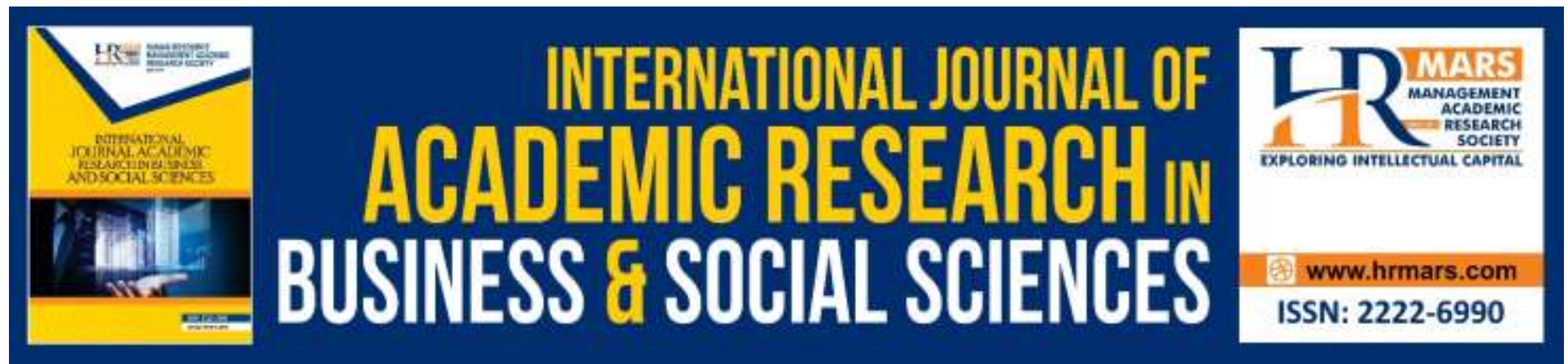

\title{
Kaizen from Islamic Perspective: A Review Paper
}

\section{Mohd Sadiq Mohd Mokhtar}

To Link this Article: http://dx.doi.org/10.6007/IJARBSS/v8-i5/4227

DOI:10.6007/IJARBSS/v8-i5/4227

Received: 07 April 2018, Revised: 22 April 2018, Accepted: 21 May 2018

Published Online: 29 May 2018

In-Text Citation: (Mokhtar, 2018)

To Cite this Article: Mokhtar, M. S. M. (2018). Kaizen from Islamic Perspective: A Review Paper. International Journal of Academic Research in Business and Social Sciences, 8(5), 874-886.

\section{Copyright: (C) 2018 The Author(s)}

Published by Human Resource Management Academic Research Society (www.hrmars.com)

This article is published under the Creative Commons Attribution (CC BY 4.0) license. Anyone may reproduce, distribute, translate and create derivative works of this article (for both commercial and non-commercial purposes), subject to full attribution to the original publication and authors. The full terms of this license may be seen

at: http://creativecommons.org/licences/by/4.0/legalcode

Vol. 8, No. 5, May 2018, Pg. 874 - 886

http://hrmars.com/index.php/pages/detail/IJARBSS

JOURNAL HOMEPAGE

Full Terms \& Conditions of access and use can be found at http://hrmars.com/index.php/pages/detail/publication-ethics 


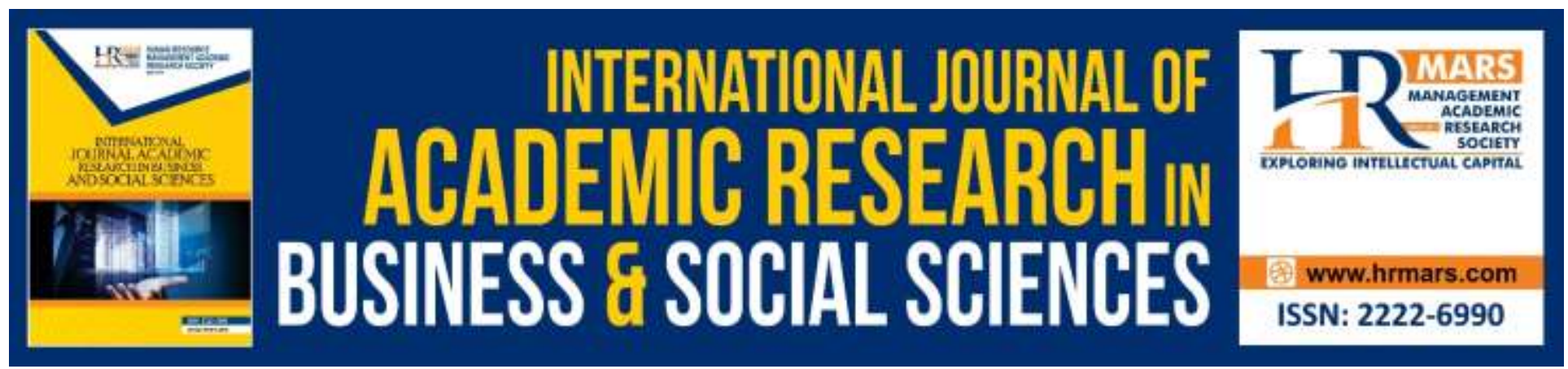

\title{
Kaizen from Islamic Perspective: A Review Paper
}

\author{
Mohd Sadiq Mohd Mokhtar \\ Centre for Islamic Development Management Studies (ISDEV), Universiti Sains Malaysia \\ Penang, Malaysia
}

\begin{abstract}
This article focus on the discussion of various literatures regarding Kaizen from Islamic perspective done by previous researchers. Kaizen has been a management philosophy that gained interest in most countries including Muslim majority countries such as Malaysia. The development of Kaizen was based only on the thought and observation of the Japanese scholar which focus on the material aspect and it was also based on Zen Buddhism expression and culture. The question which arises is what are the discussion done by previous researchers on Kaizen from Islamic perspective? And Kaizen from Islamic epistemological perspective. This article seeks to address these issues with the focus of descripting the discussion on the philosophies and development of concept. There are three different perspective of Kaizen from Islamic researchers' perspective based on the discussion of previous researchers, which are the researchers that totally accepted the Kaizen brought by the Japanese, the researchers that integrate the concept of Kaizen with Islamic values and Islamic framework and the researchers that suggest the concept of Kaizen derived from Islamic sources of knowledge. Several critics of Islam on Kaizen has been rose on the sources of knowledge in the development of Kaizen and the ultimate goals of Kaizen. This qualitative content analysis research suggests that from Islamic epistemological perspective, there are critics on the concept of Kaizen bought by the Japanese and the suitability of Kaizen to be implemented to Muslim individuals has been questionable.
\end{abstract}

Keywords: Kaizen, Continuous Improvement, Ihsan, Islamic Perspective.

\section{Introduction}

Manufacturing has been a sector that gained interest globally including Islamic countries such as Malaysia. These days, manufacturing management philosophies has been developing throughout the whole world. These philosophies originated from Scientific Management Theory. Scientific management generally focusing on the theory to maximize human productivity through the application of scientific planning (Wienclaw, 2014). This had been shown by the Japanese whom succeeded in creating a new manufacturing management model that maximizing human productivity by harnessing the intelligence in every worker as well as physical aspect of the workers (Kenny \& Florida, 1993). As a result, Japanese manufacturing has succeeded in the global market and most countries including the United States of America (USA) started learning from 
the Japanese. (Womack, Jones \& Ross, 1990). Most of the philosophies in manufacturing management originated from automotive industries due the demand for automotive products are high after World War 2 (Shingo, 1989). Therefore, one of the most prominent company in Japan is Toyota that achieve in introducing the Toyota Production System (TPS) which has been later known as Lean Manufacturing System (LMS) (Womack, Jones \& Ross, 1990). LMS later become one of the most prominent manufacturing system and has been practiced by numerous amount of organization throughout the whole world.

Malaysia is a country that rely on its manufacturing sector as a source of economy. According to Productivity Report by Malaysian Productivity Corporation (2016), manufacturing is one of the main economic sector in Malaysia alongside services and agriculture has witnessed growth for 5 years period starting on 2011. Figure 1, shows share of output and number of employment in main economic sectors in Malaysia.

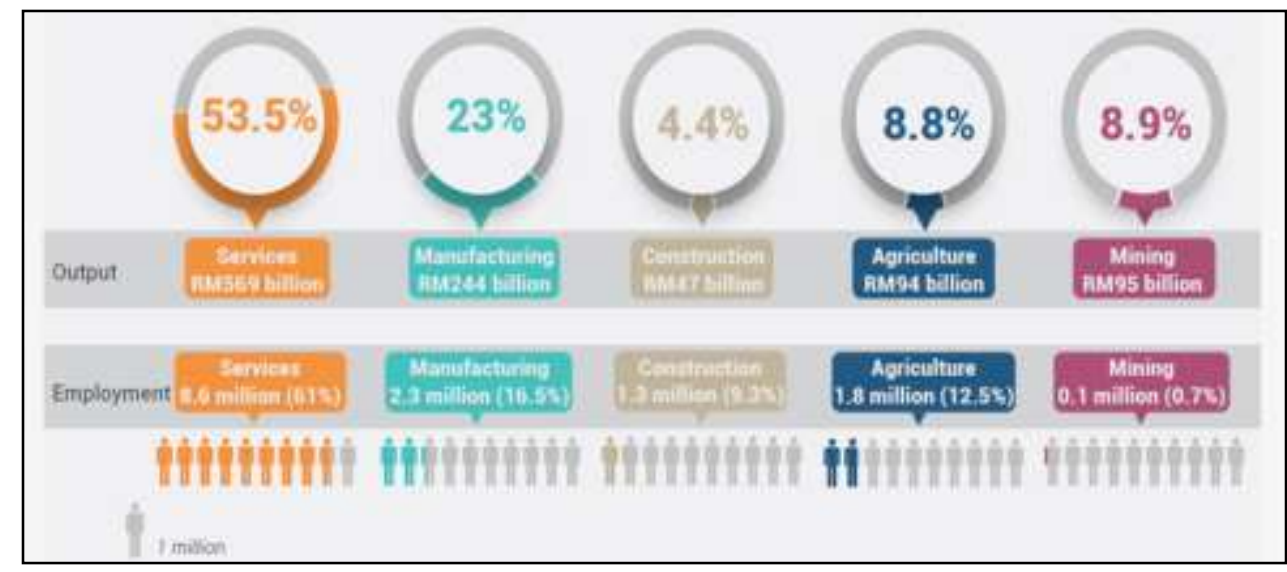

Figure 1: Share of output and number of employment in main economics sectors in Malaysia. (Malaysian Productivity Corporation, 2016)

When Malaysia 4th Prime Minister, Mahathir Mohamad introduced Look East Policy (LEP), one of the main ideas is that promoting the Japanese Manufacturing philosophy into manufacturing firms in Malaysia (Kiong, 2000). This statement is parallel with another researcher Smith (1994) and Saad and Talib (2015) which mention the main purpose of LEP is to transfer the Japanese element in management such as the values of its management and its working culture. Therefore, since LEP has been introduced, LMS started to penetrate Malaysian industries. As a result, there are numerous amount of organization in Malaysian industries such as in automotive industries and electric and electronic industries have been using this system as early as 1996 (Muslimen et al., 2011; Wong, Wong, Ali et al., 2009). Therefore, LMS has been establish and implemented in this country and still many organization have been interested in implementing it soon.

Based on the history of LMS, it consists of 5 main principle which is standardized work, JIT, Kanban, Jidoka (Automation) and Kaizen (Roser, 2016). Kaizen, the vital element of TPS which Taiichi Ohno promoted, begins with behaviour by making maximum use of everyone's brainpower to devise simple, ingenious solutions to problems (Nakane \& Hall, 2002). Imai (1986) 
mentioned that Kaizen is the key elements of Japanese successful in dominating manufacturing industries in the world. Most countries that try to implement LMS such as Malaysia eventually will be having interest in Kaizen. Effect of Kaizen in Japan was special, and some countries hope to achieve it within short period of time. However, according Paraschivescu and Cotîrleţ (2015) quality culture and way of thinking of the Japanese people contributed greatly to this achievement and therefore to implement Kaizen, the culture itself must adapt to it. Roser (2016) which mentioned that the main reason for Toyota success not because it copied manufacturing system from West, but it combined the ideas and improved it based on Toyota organization cultures.

In Malaysia, the interest to diffuse Kaizen has been initiated not only in manufacturing sector. For example, Malaysian Productivity Corporation (MPC) is one of the main government body that venture into LMS so that public and private sector will be interested to implement it. MPC had established with a roadmap for government institution. Figure 2 will show the roadmap that has been implemented in Malaysia.

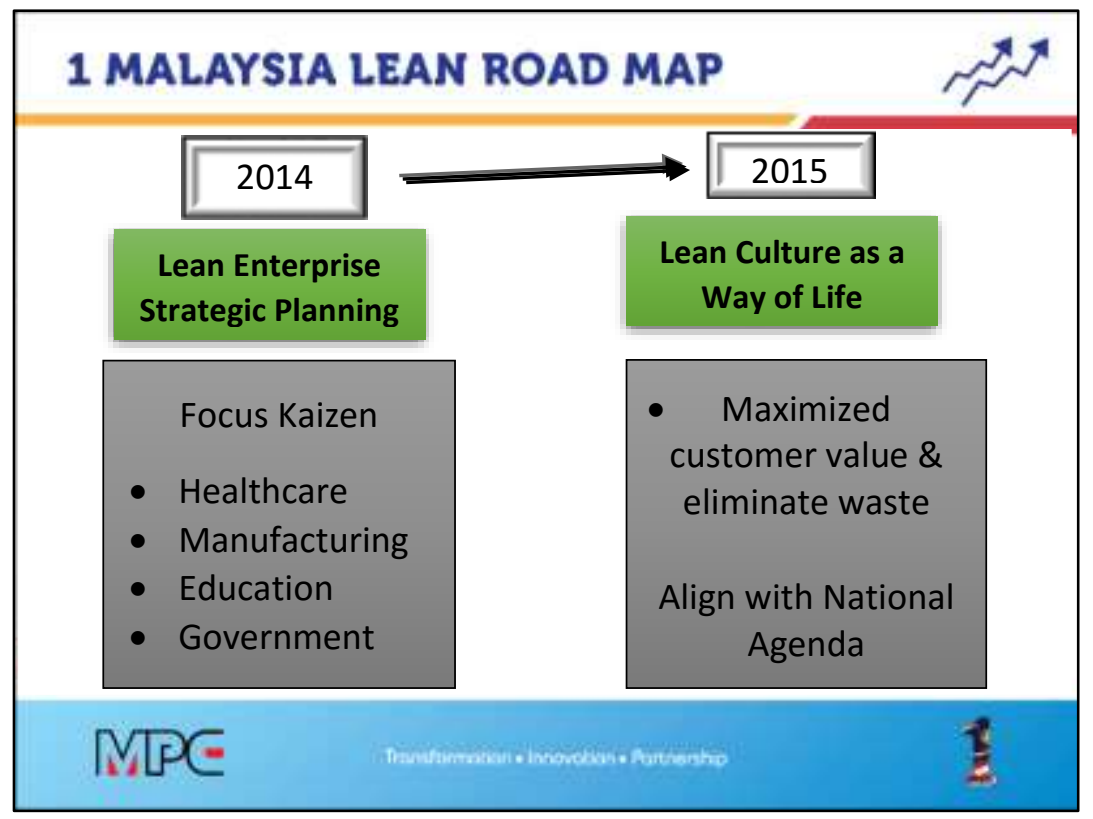

Figure 2. 1 Malaysia Lean Road Map. (Malaysia Productivity Corporation, 2016)

However, Mohamed et al., (2016) mentioned that Malaysia have been practicing manufacturing system introduced by the West and East that aimed for materialism which eventually will cause problems in manufacturing sector such as the erosion of humanity and exploitation of human labor and this include Lean Manufacturing System. Furthermore, current management theory brought by the Japanese and West attached to the value of quantitative and materialism (Ahmad, 2009). Thus, the management system brought by the Japanese and the West must be analysed first before implementing it to the Muslim.

On the other hand, even though Kaizen was originated from manufacturing sector, however, some researchers such as Prosic (2011) argued that Kaizen was easily adopted by the Japanese 
due to the concept was based on ancient tradition of the Japanese which seeks harmony through continuous improvement which is adopted from Taoist and Buddhist tradition. Furthermore, this was also mentioned by Poparat and Kellett (2006) which argue that Kaizen is directly linked with Zen Buddhism in the aspect of continuously improving. This might be causing issue with Islam due to the roots of Kaizen adopted from other religion and thus different approach in defining the purpose of this management method. Based on its nature of materialism and its closely link with other religion tradition, therefore, a research must be done on Kaizen from Islamic perspective especially the Muslim researchers perspective and Islamic epistemological perspectives.

\section{Kaizen from Islamic Perspective: Past Researchers' Views}

Manaf and Zein (2011) argue that LMS which one of its core element is Kaizen was the brilliant application for modernization of Japanese management system. Therefore, Kaizen is always link to modernization theory. According to Manaf and Zein (2011), the perspective of Muslim researchers regarding modernization divided into three which are the researchers that accepted modernization, researchers that integrate modernization with Islamic values and the researchers that rejected modernization. This research found that the discussion on Kaizen by Muslim researchers also been categorized into these three different stands with a slight different in the third category. The first category is the Muslim researchers that totally accepted Kaizen that has been bought by the Japanese and the West. The second stand is that accepted Kaizen with integration of Islamic values or Islamic Framework and the third stands was provide the continuous improvement that is from Islam that is derived from Islamic sources of knowledge.

Firstly, among the researchers that totally accepted Kaizen brought by the Japanese are Jaafar, Habidin, Hussin, Zakaria and Hamid (2013) which mentioned that to rise the status of Islamic Institution such as mosque, Kaizen system must be applied due to its success factor that eventually contributed to increase performance of the mosque. The discussion on the implementation of Kaizen on Islamic individuals also done by Asaad and Yusoff (2015) which study on the relationship between organizational culture and Kaizen implementation in Malaysia and the result of this research argue that organizational culture influences the success of implementing Kaizen. Since Malaysia is an Islamic majority country, Islamic culture among Muslim are flourish and this therefore Asaad and Yusoff (2015) suggest that organizational culture that based on Islam must be adapted by Malaysian manufacturing companies so that the success of implementing Kaizen will be achieve. Asaad and Yusoff (2015) also mentioned that the reason Kaizen is accepted with Islam due to continuous improvement always has being introduced much earlier in Islam.

Other than that, there were several Muslim researchers that totally accepted Kaizen for the reason like the argument by Asaad and Yusoff (2015) which is Kaizen has been practiced by the early Islamic Civilization. Al-Habshi (1998) mentioned that one of the greatest caliph in Islamic civilization Umar Al-Khattab RA practices Kaizen in its governance. This statement was also mentioned by Jabnoun (1994) which mentioned that, Umar Al-Khattab RA provide a controlling process that consist of the elements of continuous improvement or Kaizen in it. Under the rule of Umar al Khattab RA, many changes happen such as the increase in efficiency of management 
due to separation of jurisdiction and executive duties, the planning for economic equality, emphasizing equity and improve agriculture system by providing dam and building of canals (Ismail \& Rahman, 2011). Based on the reason above, these researchers totally accepted the Kaizen been bought by the Japanese.

Secondly, the discussion on Kaizen by the Muslim researchers are the type of researchers that integrate Kaizen with Islamic framework. Within this category, there are two type of researchers which are the one that fully integrate kaizen within Islamic framework and the ones who replace Kaizen term used by the Japanese and the West to Islamic term to satisfy the integration of Kaizen into Islamic framework. According to Mohamed, Mohamed and Rahman (2015), the integration of contemporary cultural approach works such as Lean Manufacturing with Islamic principle such as concept of al-falah, the fundamental of Tawhid, concept of Fardhu Ain and Fardhu Kifayah can create an Islamic Manufacturing Model as Figure 3.

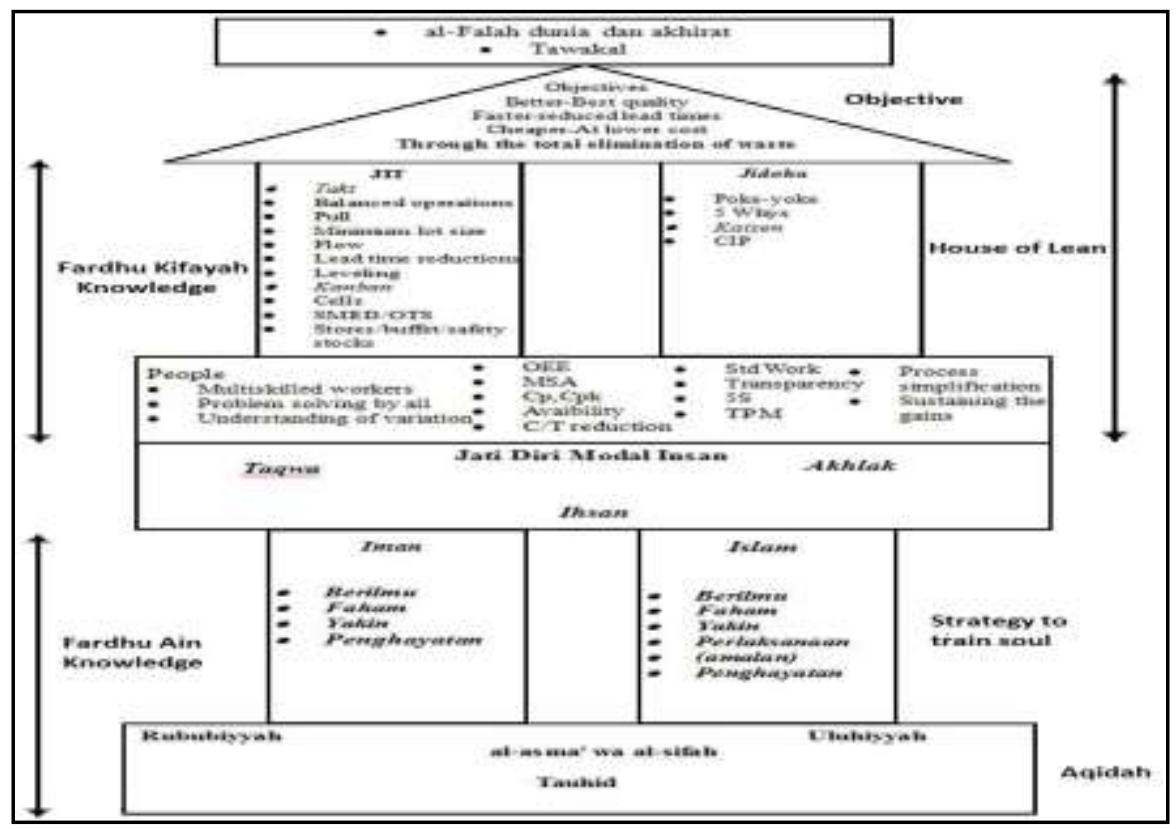

Figure 3. Islamic Manufacturing Model (Saiful Bahri et al., 2015)

Furthermore, Noh, Basir, Taib, Amadun and Husin (2015) done research on Malaysian company, Johor Corporation (JCorp) that used the term Islah for Kaizen. Islamic element that incorporated within this concept is the concept of islah itself which JCorp define as element of Islam that brings the meaning of 'to change'. However, JCorp just interchange Islah and Kaizen due to JCorp focusing in implementation of Quality Management System (ISO 9000) which indicated that Kaizen was one of the main element in that system. Therefore, to implement ISO 9000, JCorp need to use the term Islah as Kaizen element in that system and eventually term Islah used in JCorp was basically Kaizen element brought by the Japanese and the West. Hassan, Ali and Lam (2007) mentioned that ISO 9000 was the beginning of continuous improvement which led to the implementation Total Quality Management (TQM) theory. Therefore, even though the term Islah is used by JCorp, the meaning of Islah still the same with Kaizen because in ISO 9000 and TQM, Kaizen is the most vital element in it. 
Furthermore, Basir, $\mathrm{Pa}$ and Sulong (2010) was another researcher that accommodate Islamic values into Kaizen. By injecting Islamic values such as leadership which involve Islamic Leadership Model, Islamic Human Development which involve spiritual development, mental development and other Islamic values such as respect for the people into Kaizen will eventually assist organization achieve its ultimate goals which is obtain high quality products and services as customer demand (Basir, Pa \& Sulong, 2010).

Thirdly, the category that provide Kaizen from Islam. There was no clear rejection of Muslim scholars on Kaizen. However, several researchers such as Sohail and Al-Buraey (2005) which mentioned that management method that implemented onto Muslim must be based on Islamic perspective which is derived from Islamic sources of knowledge. Therefore, Sohail and Al-Buraey (2005) derived management principle which from the sources of Quran. Among principle that have been specialization of work, unity of command, unity of direction, choosing general interest over individual interest, remuneration, centralization, scalar chain, order, equity, stability, formulating and carry out plan and harmonious effort among individuals Muhammad Sadiq Sohail and Al-Buraey (2005) has provided each principle with Quranic verse according to its criteria.

Another point to consider, another researchers Bahri et al., (2016) have done similar research but focusing on the manufacturing principle. Among the Islamic manufacturing principle mention by Bahri et al., (2016) are owner, capitalization, workers, premises, tools and equipment, material resources, work processes, documentation and products. Like Sohail and Al-Buraey (2005), Bahri et al., (2016) provided each element with Qur'anic verse. Subsequently, if examined both researchers do not instill element of continuous improvement or kaizen as a principle of Islamic Management and Islamic Manufacturing that is derived from the Quran.

However, Sohail and Al-Buraey (2005) does taking account that the Japanese management succeed in surpassing the Western management due to continuous improvement (Kaizen) process that making quality a responsibility of all employees within organization. Thus, Sohail and Al-Buraey (2005) provide ihsan concept which brings out the meaning of proficiency that derived from hadith of Prophet Muhammad SAW thus confirming that ihsan concept is the Islamic concept of continuous improvement. Previously mentioned researchers, Basir, Pa and Sulong (2010) also mentioned on the concept of ihsan but the main difference between these two researchers is that Basir, $\mathrm{Pa}$ and Sulong (2010) mentioned that to achieve ihsan, the organization must use kaizen, not ihsan as the concept of continuous improvement that replace Kaizen.

Another researcher that using the term ihsan for continuous improvement is Al-Jayyousi (2012) which mentioned ihsan entails to the meaning of continuous improvement and conscious evolution of the individuals, society and the ummah. This statement linear with another researcher which is Hisyam al Talib (1991) which define ihsan as to continue improving performance without giving up. al Talib (1991) introduce training module for Islamic workers which involves three different stages which is islah (reform), ihsan (continuous improvement) and itqan (perfection). The Figure 4 shows the stages. 


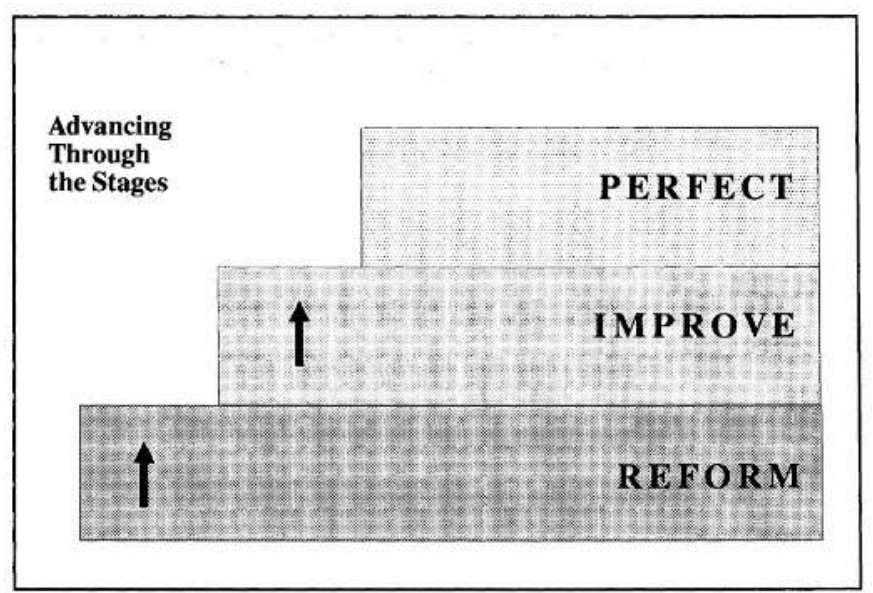

Figure 4. The Islah, Ihsan and Itqan concept (Hisyam al Talib, 1991)

Based on these three stands made by the Muslim researchers, it can be concluded that each Muslim researcher has its own interpretation of the concept of Kaizen and will be difficult to analyze whether it is suitable for Muslim individuals based on the Muslim researchers alone. Therefore, to elaborate more on this issue of suitability of implementing Kaizen on to Muslim individuals, the research on the epistemological aspect of Kaizen must be done so that the philosophical underpinning Kaizen can be obtained and gain the whether there is a critic of Islam on the concept of Kaizen.

\section{Kaizen from Islamic Epistemological Perspective}

Islam covers all aspect of human life. Islamic way of life combines in absolute coherence the work for this world and work for Hereafter and therefore Muslim does not need to waste lifetime on earth to win a better life in the next world to come nor does waste the latter to fulfil the former (Qutb, 2015). Human need to fulfil the amanah given to human as servant and vicegerent of Allah SWT which eventually establish relationship with Allah SWT and relationship with human and environment (Salleh, 2003). Therefore, Islam encompasses every aspect that are vital in this life and in hereafter

Furthermore, Kaizen has been developed by the Japanese to be culturized into organization (Nakane \& Hall, 2002). The ultimate goal of Kaizen is to continuously improve the process and organization to eliminate waste and improve so that it will conform to customer expectation and also profit maximization (Imai, 1986). The ultimate goal in Islam is to achieve the blessing of Allah SWT which then gained the happiness in this world and hereafter (Salleh, 2003). Islam does not prohibit its followers or Muslim to gaining profit or material aspect in this world, however, the material aspect cannot be the ultimate goals of this world (Ahmad, 2009). This also critic the argument made by Jabnoun (1994) and Al-Habshi (1998) regarding Saidina Umar al Khattab has been practices Kaizen because according to Ismail and Rahman (2011), the ultimate goal in every process by the governance of Saidina Umar al Khattab was to achieve al-falah which is the happiness in the world and hereafter and thus the ultimate goal of improvement process made by Saidina Umar al Khattab is different from the concept of Kaizen. Moreover, this states that the 
ultimate goal of Kaizen is totally different from the ultimate goal based on Islam and therefore integrating it with Islamic framework also will not be suitable as what has been done by Mohamed, Mohamed and Rahman (2015). This was also mentioned by Hanapi (2017) which argue that the ultimate goal of a theory that only limited to purely profit economy, human being will be considered as being of the economy, not as state by Islam which is human is a vicegerent of Allah SWT and slave of Allah SWT (Salleh, 2003) and thus integrate Kaizen with Islamic framework and Islamic values is questionable. This also suggest that the implementation of Kaizen towards Muslim individuals can be reevaluate.

Another point to consider, the Kaizen concept was developed by the observation and thought of the Japanese expertise in production system (Womack, Jones \& Roos, 1990). Therefore, the sources of knowledge in development of Kaizen is from sense and thought of the Japanese scholars such as Taiichi Ohno, Shigeo Shingo and Masaaki Imai. Shingo graduate in mechanical engineering (Ahmad, 2009) which he graduated from Yamanashi Technical College in 1930 he went to work for the Taipei Railway Company (Bodek, 1989) and eventually become one of the greatest contributor to modern manufacturing practices (Vardeman, nd) and be called as Thomas Edison of the Japanese. Shingo pioneered JIT that eventually developed in LMS and the Shingo process of observation and reflection and determination to improve then developed Kaizen (Bodek, 1989). Another scholar on Kaizen is Masaaki Imai. Imai was born in Tokyo and graduate in Accounting and pursue graduate work in international relation and has been consulting companies globally on various kaizen management practises (Institute, 2009). The most prominent scholar in Kaizen is Taiichi Ohno. Ohno graduated from Nagoya Technical High School. He joined Toyota in 1932 (Bodek, 1989). The above highlight several issues. that the education background of this scholars on the development of Kaizen theory was mainly on technical aspects. Another point to consider is that this scholar has no association with Islam and eventually neglect Islamic sources of knowledge in developing Kaizen theory. Islam suggest the assimilation between the nadhari knowledge ${ }^{1}$ which is obtain from the Islamic sources of knowledge which is al-Quran, Hadith of Prophet Muhammad SAW, ijmak and qiyas and daruri knowledge ${ }^{2}$ (Ahmad, 2009; Salleh, 2003; Hanapi, 2014). The Kaizen concept that only based on daruri knowledge does not have the ability to analyse problem that not perceptible to be interpret by sense and thoughts. Therefore, this also one of the critics of Islam which is the sources of development of Kaizen is from the sources that does not covers all aspect that is required for human more specifically Muslims.

\section{Conclusion}

The discussion in this paper presented the stands or perspective taken by previous researchers regarding Kaizen from Islamic perspective. Previous researchers produce three stands on Kaizen

${ }^{1}$ Nadhari knowledge is knowledge obtained from Islamic sources of knowledge which is alQuran, Hadith of Prophet Muhammad SAW that provide the naqli sources for human (Muhammad Syukri Salleh, 2003)

2 Daruri knowledge is knowledge obtained from the sence and thought (Muhammad Syukri Salleh, 2003) 
from Islamic perspective which is totally accepted Kaizen, integrate Kaizen with Islamic framework and values and the researchers that provide Kaizen in Islam based on Islamic sources of knowledge. Furthermore, this discussion also discussed on the Kaizen from Islamic Epistemological Perspective. The result shows that Kaizen ultimate goals and the sources of knowledge in the development of Kaizen has not been align with Islam and thus Kaizen is inappropriate to be implemented towards Muslim individuals. Another point to consider, this paper also suggests the continuous improvement element in Islam which is the concept of ihsan as mentioned by previous researchers that provide the concept of Kaizen based on Islamic sources of knowledge. Therefore, the research on the concept of ihsan must be further review so that much more appropriate concept of Kaizen to be implement can be produce which is based on the sources of knowledge in Islam and its ultimate goals is align with Islam.

\section{Acknowledgement}

Alhamdulillah, all praises to Allah SWT for the strengths and His blessing in completing this research. Special appreciation goes to my supervisor, Dr Fadzila Azni Ahmad, for her supervision and constant support. Her passion and invaluable help of constructive comments and suggestions throughout the development of this research. Not forgotten, my appreciation to all lecturer of ISDEV, supporting staff of Universiti Sains Malaysia (USM), librarian of Hamzah Sendut USM for their support and knowledge. I would like to express my appreciation to the expertise of Lean Manufacturing System in Malaysia such as Dr. Nurul Fadly Habidin, Mrs. Rusalbiah Che Mamat and Mr. Kamal Sabri Kamarudin for sharing their extensive knowledge in manufacturing area. Sincere thanks to all colleague from MISDEV 16.1 for their kindness and moral support during my study. Thanks for the friendship and memories. Finally, my deepest gratitude goes to my beloved parents; Prof Mohd Mokhtar Saidin and Mrs. Ruslaini Othman and to my siblings for their endless love, prayers and encouragement. May Allah SWT bless them with great success in this world and hereafter.

Corresponding Author: Mohd Sadiq Mohd Mokhtar.

Centre for Islamic Development Management Studies (ISDEV),

Universiti Sains Malaysia, 11800 Minden, Penang, Malaysia

Email: sadiqmokhtar@gmail.com

\section{References}

Abdulmouti, H. (2015). The Role of Kaizen (Continuous Improvement) in Improving Companies' Performance: A Case Study. UAE: Proceedings of the 2015 International Conference on Industrial Engineering and Operations Management.

Ahmad, F. A. (2008). Kaedah Pengurusan Institusi-Institusi Pembangunan Berteraskan Islam di Malaysia. Universiti Sains Malaysia: Thesis ISDEV

Ahmad, F. A. (2009). Total Quality Management (TQM) from Islamic Perspective an Epistemological analysis. Universiti Sains Malaysia. ISDEV paper series

Ahmad, F. A. (2012). Philosophical Underpinnings of Islamic Management Method: Worldview, Epistemology and Ontology. International Journal of Humanities and Social Science, 2(20).

Ahmad, F. A. (2016). Konsep Pengurusan Institusi Pembangunan Berteraskan Islam. Kuala Lumpur: Dewan Bahasa dan Pustaka 
INTERNATIONAL JOURNAL OF ACADEMIC RESEARCH IN BUSINESS AND SOCIAL SCIENCES

Vol. 8, No. 5, May 2018, E-ISSN: 2222-6990 @ 2018 HRMARS

Al-Habshi, S. O. (1998), Islamic Management for Excellence - Revitalizing People for the Future. Management ethics. Kuala Lumpur: INMIND.

Al-Jayyousi, O. R. (2012). Islam and Sustainable Development. New Worldview (Transforming and Innovation). Gower Publishing Limited. England

Al-Qudsy, S. H. S. I. \& Ab Rahman, A. (2011), Effective Governance in the Era of Caliphate 'Umar Ibn Al-Khattab (634-644), European Journal of Social Sciences,Volume 18, Number 4 , pp 612-624.

Al-Talib, H. (1991). Training Guide for Islamic Workers. The International Institute Of Islamic Thought, Pakistan: Karachi

Asaad, M. N. M. \& Yusoff, R. Z. (2015). Kaizen Implementation in Improving Organizational Excellence in Islamic Perspective. Ulum Islamiyyah Journal, 15, 23-43

Aurel T. M., Simina R. A., and Stefan, T. (2015). Continuous Quality Improvement In Modern Organizations through Kaizen Management. 9th Research/Expert Conference with International Participations 2015.

Bahri, M. S., Ab Rashid, R., Abdullah, A. H., Wahab, Z., Ab Rahman, H. A., Mohd, A., ... Besar, R. (2016). A review of key principles in halal manufacturing. International Journal of Applied Business and Economic Research, 14(14), 1239-1249.

Bahri, M. S., Aziz, W. A., \& Rahman, H. A. (2015). Islamic Manufacturing Model. Academia.Edu. Retrieved from http://www.academia.edu/download/39623782/unisza-IAC.pdf

Bahri, M. S., Zainal, S., Hakim, A., Zainal, S., \& Zainal, S. (2016). Islamic Manufacturing: Philosophy, Principles and Practices. Proceedings of SOCIOINT 2016 3rd International Conference on Education, Social Sciences and Humanities ISLAMIC, (August), 168-175.

Basir, S. A., Pa, C. B. \& Sulong R. A. (2010). Islamic values injection to Continuous Improvement and ISO 9001 as device in producing high quality products and services, Shariah Journal 18 (1): 91-122. APIUM, UM Publisher.

Becker R. M. (2001). Lean Manufacturing and Toyota Production System. SAE International in Manufacturing.

Bodek N. (1989). A Study of the Toyota Production System from an Industrial Engineering Viewpoint, Publisher's Foreword. Cambridge: Productivity Press.

Chen, T. (2016). Competitive and Sustainable Manufacturing in the Age of Globalization, Sustainability 2017, 9(26), 1-5

Department of Statistic Malaysia. (2015). Report on Survey Of Manufacturing Industries 2015.

Habidin, N. F., \& Yusof, S. M. (2013). Critical success factors of Lean Six Sigma for the Malaysian automotive industry. International Journal of Lean Six Sigma, 4(1), 60-82.

Hanapi M. S. (2014). Tasawur Islam dan Pembangunan. Kuala Lumpur: Dewan Bahasa dan Pustaka

Hanapi, M. S. (2017). Tasawur Teori Pembangunan Lazim: Analisis Daripada Perspektif Tasawur Islam. Jurnal Hadhari, 9(1), 49-62.

Hassan, M., Ali, M. M. \& Lam, T. H. K. (2007). ISO 9000 and TQM for Business Excellence.

Hidzry, N. A. S. (2017). Creanova Lean 2017[Blog Post]. Retrieved from http://blog.miti.gov.my/index.php/blogs/view/948

Imai, M. (1986). Kaizen the key to Japan's competitive success, USA: McGraw Hill Inc

Imai, M. (2012). Gemba Kaizen a Commonsense Approach to a Continuous Improvement Strategy, USA: McGraw Hill, 1-11 
INTERNATIONAL JOURNAL OF ACADEMIC RESEARCH IN BUSINESS AND SOCIAL SCIENCES

Vol. 8, No. 5, May 2018, E-ISSN: 2222-6990 @ 2018 HRMARS

Jaafar J., Habidin, N. F., Hussin, M. Y. M., Zakaria, Z., \& Hamid, A. A. (2013). Relationship Between Strategic Management(Sm) and Kaizen Management System (Kms) in Mosque Management. BEST: International Journal of Management, Information Technology and Engineering (BEST: IJMITE), 1(3), 15-20. Retrieved from http://www.bestjournals.in/view_archives.php?year=2013_14_2\&id=14\&jtype=2\&page= 2

Jabnoun, N. (1994). Islam and Management. Kuala Lumpur: Institut Kajian Dasar (IKD).

Kaizen Institute. (2009). The biography of Masaaki Imai. Kaizen Institute Itd

Kenny, M., \& Florida, R. (1993). Beyond Mass Production: Japanese System and its transfer to the USA. New York: Oxford University Press

Kiong, F. (2000). The Look East Policy: It's Impact in Promoting Japanese Management Techniques to Manufacturing Firms in Malaysia. University of Stirling: Thesis Department of Management and Organization

Kootanaee, A. J., Babu, K. N., \& Talari, H. F. (2013). Just-in-Time Manufacturing System: From Introduction to Implement. International Journal of Economics, Business and Finance. 1 (2), 7-25.

Krafcik, J. F. (1988). Triumph of the Lean Production System, Sloan Management Review, 1(30), 40-52

Malaysia Productivity Corporation. (2016). Lean Management [Official Website]. Retrieved from http://www.mpc.gov.my/leanmanagement/

Malaysia Productivity Corporation. (2016). Productivity Report 2015/2016 [Official Website]. Retrieved from http://www.mpc.gov.my/wp-content/uploads/2016/06/ProductivityReport-2016.pdf

Manaf, N. A., \& Zein I. M. (2011). Lean Management and Islamic Perspective: convergence in diversity. Spirituality in Management from Islamic Perspective. Selangor: IIUM Press

Muslimen, R., Yusof, M., Sakura, A., \& Abidin, Z. (2011). Lean Manufacturing Implementation in Malaysian Automotive Components Manufacturer: a Case Study. Proceedings of the World Congress on Engineering 2011, 6-10. https://doi.org/10.1007/978-1-4614-2317-1

Nakane, J., \& Hall, R. W. (2002). Ohno's Method Creating a Survival Work Culture. First Quarter 2002. 18(1), 6-15

Noh, M. M., Basir, S. A., Taib, L., Amadun, M., \& Husin, W. N. H. W. (2015). Kajian Kes Perlaksanaan Etika Kerja Islam (EKI) di Johor Corporation (JCorp): Tumpuan kepada Perlaksanaan dan Faedahnya. Jurnal Pengurusan. Penerbit Universiti Kebangsaan Malaysia.

Ohno, I. Ohno, K., \& Uesu, S. (2009). Introducing Kaizen in Africa. Tokyo: GRIPS Development Forum Tokyo: Roppongi, Minato-ku.

Paraschivescu, A. O., \& Cotîrleţ P. C. (2015). Quality Continuous Improvement Strategies Kaizen Strategy - Comparative Analysis. Economy Transdisciplinary Cognition, 18(1), 12-21

Poparat, J., \& Kellet, A. (2006). Buddhism and TQM: An alternative explanation of Japan's adoption of Total Quality Management. Proceedings of the 20th ANZAM Conference 1-19

Prosic, S. (2011). Kaizen Management Philosophy. Serbia: International Symposium Engineering Management and Competitiveness 2011 (EMC2011)

Qutb, S. (2015). Tafsir Fi Zilalil Quran [Opensource]. Retrieved from https://archive.org/details/TAFSIRFIZILALILQuranSayyidQuthbEnglish 
INTERNATIONAL JOURNAL OF ACADEMIC RESEARCH IN BUSINESS AND SOCIAL SCIENCES

Vol. 8, No. 5, May 2018, E-ISSN: 2222-6990 @ 2018 HRMARS

Roser, C. (2016). Origin of Lean and Lesson for today [Keynote Presentation Slides]. Retrieved from http://www.buckingham.ac.uk/wp-content/uploads/2016/09/130916-Keynote12.0012.45hrs-Prof-Dr-Christoph-Rose-Karlsruhe-University-of-Applied-Sciences.pdf

Salleh, M. S. (2003). 7 Prinsip Pembangunan Berteraskan Islam. Kuala Lumpur: Zebra Edition Sdn. Bhd.

Samuri, H. (2017). CREANOVA LEAN 2015. Retrieved from http://www.mpc.gov.my/creanovalean-2015/

Shingo, S. (1989), A Study of the Toyota Production System from an Industrial Engineering Viewpoint. Cambridge: Productivity Press.

Sohail, M. S., and Al-Buraey, M. (2005). TQM practices and organizational performances in the manufacturing sector: evidence from a developing nation. International Journal of Business Performance Management, Vol.7, No.2

Thomas J., Harden A. (2008). Methods for the Thematic Synthesis of Qualitative Research in Systematic Reviews. BMC Med Res Methodol 45(8)

Vardeman, B. S. (nd). The impact of Dr Shigeo Shingo on Modern Manufacturing Practises [Keynote Presentation Slides]. Retrieved from http://www.public.iastate.edu/ vardeman/IE361/f02mini/bumblauskas.pdf

Wienclaw, R. A. (2014). Scientific Management in Organization. Research Starters Sociology. lowa: Great Neck Publishing

Womack, J. P., Jones, D. T., \& Ross, D. (1990). The Machine that Changed the World. New York: Rawson Associates

Wong, Y. C., Wong, K. Y., \& Ali, A. (2009). A study on lean manufacturing Implementation in the Malaysian electrical and electronics industry. European Journal of Scientific Research, 38(4), 521-535.

Yanow, D., and Schwartz-Shea, P. (2006). Interpretation and method: Empirical research methods and the interpretive turn. Armonk, NY: M.E. Sharpe. 